\title{
DE COLONOS DESEJADOS A MORADORES INDESEJADOS: UM ESTUDO SOBRE A IDENTIDADE E SOCIABILIDADE ENTRE IMIGRANTES (PONTA GROSSA-PR, FINAL DO SÉCULO XIX)
}

\author{
From Desired County Men Neighborhood to Unwanted \\ Citizens: a Study about Identity and Socialization \\ among Immigrants (Ponta Grossa City \\ end of the Nineteenth Century)
}

Renata Sopelsa*

\begin{abstract}
RESUMO
Primavera de 1895, noite fria, ruas escuras, mas em uma das casas comerciais da pequena cidade do interior do Paraná desenrolava-se um baile, animado por música e bebidas. Era uma festa de imigrantes, a festa dos russos, italianos, alemães, portugueses e outros "novos moradores" que, havia pouco tempo, tinham chegado a Ponta Grossa em busca de uma vida melhor. Com efeito, o povoado, que nasceu no Caminho das Tropas e que ao longo do oitocentos era formado por uma sociedade escravocrata e rural, nesse outro momento histórico passou a abrigar centenas de imigrantes europeus atraídos pelo poder político regional, que os percebia como "colonos morigerados" capazes de resolver a carência de mão de obra no estado. Mas, alheios a essa visão romantizada, uma vez instalados, esses indivíduos passaram por um processo de adaptação a esse novo mundo social, buscando reconstruir suas redes de sociabilidade e inserir-se na sociedade local, deixando assim de serem vistos como "estranhos". Todavia, esse processo de ressocialização não transcorreu sempre de maneira tranquila, sem traumas. Por vezes, no contato com o "outro" deu-se o embate, o conflito, deu-se o crime. Assim, é com base em processos criminais que este artigo tem

* Doutoranda em História - UFPR.
\end{abstract}


por objetivo analisar as formas de inserção dos imigrantes europeus em meio à sociedade ponta-grossense, ressaltando a necessidade por eles vivenciada de reconstruir suas identidades culturais perante os inevitáveis conflitos com as famílias mais antigas da cidade.

Palavras-chave: imigrantes; identidade; sociabilidade.

\begin{abstract}
Spring 1895, cold night, dark streets, but in one of the commercial houses of the small city in the Parana state was a ball, animated by music and drinks. It was a party of immigrants, the party of the Russians, Italians, Germans and other "newcomers" that had come to the Ponta Grossa recently searching for better life conditions. The settlement created in the Way of the troops and that over the eighteen hundreds was made of a slave and country society, in another historic moment has housed hundreds of European immigrants attracted by the regional political power, which he perceived as "settlers tempered" able to resolve the poor labor offer in the state. But unrelated to this romanticized view, once installed these individuals have gone through the process of adaptation to this new social world, seeking to rebuild their networks of sociability and insert themselves into local society, and not been seen as "foreign" anymore. However, this process of rehabilitation is not always passed seamlessly, without trauma. Sometimes in contact with the "other" there was struggle, conflict and crime. Thus, is based on criminal cases that this paper aims to examine ways of European immigrant integration into Ponta Grossa city society, highlighting the need they have experienced to rebuild their cultural identity before the inevitable conflicts with the older local city families.
\end{abstract}

Key-words: immigrants; identity; sociality.

Outubro de 1895. Noite fria. Ruas escuras e vazias, recortadas aqui e ali pelas luzes do interior das residências de família que, como de costume nas cidades do interior, já haviam se recolhido ao lar ao cair da tarde. No entanto, nos arredores do núcleo urbano, onde as construções estavam mais aglomeradas, existia ainda movimento. Com efeito, entre as casas iluminadas por velas e lampiões, uma não abrigava apenas famílias, mas pessoas muito diferentes entre si que se reuniram à noite para dançar, beber, dar risadas, quem sabe para relembrar outros momentos de suas vidas, outros países. Frequentava essa festa um grande número de imigrantes, homens e mulheres que começaram a chegar a Ponta Grossa havia pouco mais de uma década. 
Com obviedade, enquanto estranhos nessa sociedade, esses outsiders ainda estavam em processo de adaptação ao novo mundo sociocultural. Buscavam reconstruir suas redes de sociabilidade, tecendo novas amizades e integrando-se aos espaços não somente de trabalho, mas também de lazer que lhes eram ofertados. Não raro, aliás, na falta de opção que os agradasse, eles mesmos criavam seus momentos lúdicos, tais como os bailes realizados nas casas comerciais ou no interior de suas residências, bailes esses sempre animados por gaiteiros e muita bebida ${ }^{1}$.

Todavia, nem sempre eram bem vistos pelos antigos moradores que, recolhidos ao lar ou promotores de festas descritas como menos barulhentas, reprovavam a sua forma de diversão.

Assim, por vezes, o processo de ressocialização que escolhiam os levava a serem estigmatizados, tidos como desviantes, indivíduos fora da ordem, sobremaneira quando em algumas oportunidades seus encontros festivos terminavam em desavenças ou crimes, como naquela noite de outubro. É, portanto, partindo dos fatos ocorridos nesse baile, bem como de outras narrativas de festas contidas em processos criminais, que este artigo tem o interesse de analisar a trajetória de inserção dos imigrantes europeus em meio à sociedade ponta-grossense do final do século XIX. Importa-nos ressaltar a necessidade por eles vivenciada de reconstruir suas identidades culturais e, nesse ínterim, os inevitáveis embates que surgiram com as famílias mais antigas da cidade.

\section{Ponta Grossa: um novo espaço sociocultural}

Nos últimos anos do oitocentos, a tranquila cidade, localizada na região que ficou conhecida na rota dos tropeiros como Campos Gerais,

1 Este artigo tem como ponto de partida a análise de um processo-crime por lesões corporais, iniciado em 12 de outubro de 1895, na Comarca de Ponta Grossa-PR, sendo que o delito teria ocorrido durante um baile que se realizava naquela noite em uma das casas comerciais da cidade. Esse processo será abordado com mais detalhes no decorrer do texto. Deve-se salientar que a escolha dessa fonte, bem como das demais a serem citadas, deu-se perante a perspectiva do historiador em contemplar os crimes e contravenções ocorridos em momentos de diversão, sobremaneira bailes, na cidade de Ponta Grossa, no final do século XIX. A partir da leitura e da análise desses processos, deu-se o encontro com os imigrantes, atores presentes e participantes nesses divertimentos. E desse encontro surgiram o trabalho aqui apresentado e a pesquisa histórica em andamento no curso de Doutorado em História, na UFPR. 
experimentava um significativo crescimento demográfico e econômico. A esse tempo, chegavam ao seu espaço urbano os trilhos da linha férrea São Paulo-Rio Grande, somando-se a outra já concluída e que fazia a sua ligação com a cidade de Paranaguá, servindo para o escoamento de madeira e de erva-mate até o porto. Aliás, juntas, essas estradas de ferro tornaram-se símbolo do limiar de "novos tempos"2.

Efetivamente, aos olhos de seus moradores a cidade deixava de ser apenas o ponto de parada de tropas e tropeiros para abrigar pequenas fábricas e casas comerciais, ou seja, deixava o passado marcadamente rural para desfrutar dos "benefícios do progresso".

Vale citar que Ponta Grossa teve sua formação histórica fundamentada na produção de grandes propriedades rurais, que representavam verdadeiras unidades socioeconômicas, afinal revelavam uma economia quase autárquica voltada para o comércio do gado e para uma produção de subsistência, atividades em que era empregada a mão de obra escrava. Afora os cativos, nelas também viviam os agregados, indivíduos que compunham uma camada intermediária, haja vista que, apesar de livres, trabalhavam sem remuneração. No decorrer do tempo, esses indivíduos e seus patrões inseriram-se no comércio das tropas.

Atraídos pela possibilidade de aumentar seus lucros, os fazendeiros percorriam os caminhos que iam da Província de São Pedro em direção à feira de Sorocaba e, ao seu lado, uma parcela significativa da população campeira, "estabelecendo um contínuo contato com os paulistas e rio-grandenses", de modo que "os habitantes dos Campos Gerais tinham, sobretudo, costumes de gaúchos"”.

Perante a troca de experiências entre os membros das comitivas, faz-se pertinente afirmar que na primeira metade do século XIX a população

2 A estrada de ferro que ligava o Porto de Paranaguá ao interior do Estado chegou a Ponta Grossa em 1894 e, em seguida, começaram a ser construídas, a partir desse ponto, duas frentes de ampliações, uma em direção a Itararé e outra ao sul, com final em Santa Maria, no Rio Grande do Sul. MONASTIRSKI, Leonel Brizola. A mitificação da ferrovia em Ponta Grossa. In: DITZEL, Carmencita de Holleben M.; SAHR, Cicilian Luiza Löwen. Espaço e cultura: Ponta Grossa e os Campos Gerais. Ponta Grossa: Ed. UEPG, 2001, p. 39.

3 Para Salvador José Coelho, filho de fazendeiros da Lapa que percorreu a região e acabou editando em 1860 um opúsculo intitulado "Passeio a minha terra", esses homens possuíam costumes "em muitíssimos pontos" semelhantes aos da Província de São Pedro, "pois não falando no traje que é o mesmo", estes também andam armados e pronunciam palavras espanholas em suas conversações. Apud: BALHANA, Altiva Pilatti; MACHADO, Brasil Pinheiro. Campos Gerais: estruturas agrárias. Curitiba: UFPR, 1968, p. 38. 
espalhada pelas vilas e pousos dos Campos Gerais construiu uma trama social singular, onde escravos, agregados, fazendeiros, velhos, jovens, mulheres e crianças conviviam em um ambiente dominado pelas lides campeiras, pelo trato de animais e, dessa experiência, instituíram um modo de vida específico. É importante ressaltar ainda que se tratava de uma sociedade hierarquizada e alicerçada no paternalismo dos grandes proprietários rurais, detentores do poder político regional ${ }^{4}$.

Mais para o final do século, no entanto, com a construção das ferrovias ligando a região cafeeira ao porto de Santos e a decadência eminente do tropeirismo, essa sociedade campeira sofreu transformações ${ }^{5}$. Nesse período, os donos das terras e suas famílias transferiram suas moradias para o núcleo urbano e, entre eles, para além de comerciantes e pecuaristas, estão rapazes que haviam se formado bacharéis em São Paulo, Pernambuco ou até na Europa.

Com o tempo, também os trabalhadores das fazendas que não encontravam mais colocação no campo dirigiram-se para o meio urbano, a eles vindo somar-se diversos migrantes vindos de outros municípios do Paraná, muitos de outros estados, à procura dos empregos trazidos com a construção das linhas férreas. Ponta Grossa enfim crescia, tornando-se gradativamente um novo espaço sociocultural, pois já não comportava mais algumas poucas e esparsas casas de comércio destinadas a atender aos tropeiros. Ganhava ares de cidade. Passava a abrigar indivíduos estranhos... Entre eles centenas de imigrantes.

\section{Os imigrantes: moradores (in)desejados}

Com efeito, a vinda desses imigrantes seguia os passos do projeto iniciado há algumas décadas no Paraná e que ganhou contornos mais ní-

136.

4 PEREIRA, Magnus R. M. Semeando iras rumo ao progresso. Curitiba: UFPR, 1997, p.

5 Nesse momento manifestou-se uma crise nos negócios de invernagem, que entraram em deterioração em virtude da nova conjuntura econômica nacional. Os mercados compradores do gado já contavam com diversas fontes de suprimento; ademais, a construção das ferrovias gradativamente foi abatendo o transporte da produção no lombo de mulas. 
tidos após a sua emancipação política, ocorrida em $1853^{6}$. Na verdade, as motivações em fixar elementos estrangeiros orientaram-se pela carência de gêneros alimentícios, que obrigava a população regional a importar artigos do exterior e de outras províncias, comprados a altos preços. Os imigrantes passaram a ser então considerados capazes de romper com tal carência, pois, na visão da elite paranaense, esses "colonos morigerados e laboriosos" iriam resolver a escassez de mão de obra, agravada a partir do remanejamento dos cativos para a lavoura cafeeira, e sanar a crônica crise de abastecimento com o incremento de novas técnicas de produção agrícola ${ }^{7}$.

Concomitantemente, buscavam ainda garantir a ocupação territorial e, sem dúvida, excluíam de seus planos o concurso da população indígena. Mais ainda, para eles era premente romper com a herança escravocrata, posto que o negro, "violento e nada confiável", não possuía "condições morais, nem culturais" para tal empreitada. Alinhados ao ideário vigente em outras partes do Brasil, concebiam o imigrante europeu como "pacífico e trabalhador" e, portanto, capaz de regenerar o elemento nacional. Dessa maneira, a imigração era considerada um "fator étnico de primeira ordem destinado a tonificar o organismo nacional abastardado por vícios de origem e pelo contato que teve com a escravidão"8.

No que tange a Ponta Grossa, entre 1877 e 1878 chegaram ao município 2.381 "russos-alemães", sendo distribuídos por 17 núcleos coloniais afastados do núcleo urbano9. Cabe ressaltar que as lideranças políticas locais justificaram o interesse em receber os chamados "alemães do Volga" igualmente usando a preocupação em criar uma agricultura de abastecimento,

6 Cabe lembrar que os primeiros grupos de europeus desembarcaram no Brasil ainda nas primeiras décadas do oitocentos, estimulados pelas políticas de colonização criadas pelas autoridades brasileiras. Segundo as ideias vigentes na época, fazia-se necessário ocupar os "vazios populacionais" e introduzir no país novas e produtivas técnicas agrícolas, ensinando-as aos terra-tenentes, junto com as virtudes do trabalho. Nesse contexto, centenas de imigrantes de origem alemã foram encaminhados para a região sul, onde fundaram, entre outras, as colônias de São Leopoldo, criada em 1824, e Rio Negro, em 1829, localizadas, respectivamente, no território que atualmente corresponde aos Estados do Rio Grande do Sul e Paraná. NADALIN, Sérgio. Paraná: ocupação do território, população e migrações. Coleção História do Paraná: textos introdutórios. Curitiba: SEED, 2001.

cit., p. 73.

7 Relatórios de Presidentes da Província do Paraná, 1855, p. 21. In: NADALIN, Sérgio. Op.

8 Relatórios de Presidentes da Província do Paraná, 1888, p. 26. In: NADALIN, Sérgio. Op. cit., p. 72 .

9 PINTO, Elisabete; GONÇALVES, Maria Ap. Ponta Grossa: um século de vida. 1823-1923. Ponta Grossa: Ed. UEPG, 1983, p. 111. 
tendo em vista a quase inexistência de indivíduos que desejassem trabalhar a terra e nela produzir alimentos, e não somente cuidar do gado.

De acordo com Guisela Chama, os fazendeiros dos Campos Gerais não desejavam investir na agricultura, "talvez por falta de mão de obra, pois as leis estavam extinguindo a escravidão negra que fatalmente iria desaparecer", e certamente porque, a exemplo do que ocorria em outras partes do país, "na época trabalhar no campo como agricultor, com os recursos que existiam, não era muito dignificante, principalmente para uma sociedade que considerava o trabalho de curvar a coluna vertebral e manejar a enxada, sujar as mãos com terra não muito aceitável". Tratava-se de um trabalho "para escravos e nunca para um branco que se prezasse". Assim, diante da falta de braços dispostos a plantar, "a única saída era encontrar quem o fizesse"10.

Todavia, por mais que se dedicassem ao plantio, inúmeras famílias de imigrantes nada conseguiram produzir, afinal foram assentadas em terras vendidas ao governo provincial por fazendeiros locais, terras que eram inadequadas para a agricultura e que nada produziam, pois o solo arenoso servia apenas para o pasto. Desse modo, muitos "russos-alemães" que vieram para trabalhar na agricultura acabaram em pouco tempo dirigindo-se para a cidade. Mais para o final do oitocentos, juntamente com eles, homens e mulheres de outras nacionalidades também construíram suas casas na cidade.

De fato, contribuindo para a expansão do espaço urbano, esses imigrantes passaram a marcar sua presença na sociedade local já na técnica e no estilo de construção de suas moradias. É interessante destacar que, conhecedores das técnicas de trabalho com a madeira, acabaram inovando as habitações até mesmo dos brasileiros, pois eram excelentes artesãos, marceneiros e carpinteiros.

Além dessas atividades, esses indivíduos sobressaíram-se nos ramos comerciais, pois suas vendas iam de alfaiatarias e açougues até diversas casas de secos e molhados. Outros ainda alcançaram sucesso no ramo industrial, montaram pequenas fábricas de banha, olarias, curtumes e fábricas de bebidas. Doravante, tanto os imigrantes que permaneceram no campo como estes que passaram a exercer atividades urbanas tornaram-se atores sociais nas redes e tramas de sociabilidade que formavam a sociedade ponta-grossense. 1988 , p. 44.

10 CHAMA, Guisela Frey. Ponta Grossa: o povo, a cidade e o poder. Ponta Grossa: PMPG, 
Concerne que, refletida e irrefletidamente, esses "estrangeiros" buscaram relacionar-se com os grupos já existentes e deixar para trás a imagem de "recém-chegados", sendo levados a fazer ajustes em seu comportamento e mudanças em seus hábitos, visando integrar-se às normas e valores característicos desse novo mundo social. Passaram, nesse sentido, por uma espécie de processo de contenção de certas emoções, instintos e traços de personalidade para fazerem-se aceitos pelos moradores antigos ${ }^{11}$.

Nessa vertente, é lícito pensar esse processo de adaptação dos imigrantes alinhando-se aos estudos de Baechler acerca das características que a sociabilidade exige dos indivíduos que compõem uma mesma formação social, pois para integrá-la "cada um deve, de algum modo, oferecer-se aos outros como membro aceitável de um círculo de civilidade”. Ou seja, em certa medida os participantes devem impor diversas limitações quanto à sua postura em grupo, assim como "amenizar com tato as asperezas de sua personalidade"12.

Todavia, nem sempre a preocupação em deixar a imagem de "estranhos", de "diferentes" acompanhava os imigrantes. Muitos negligenciaram o alcance mais profundo de assumir uma melhor posição nessa outra figuração social, deixando de ser outsider ${ }^{13}$. Estavam sim imersos em outro "mundo", mas nem por isso deixaram de exibir seus valores e costumes, mesmo que diferentes dos nacionais, tais como sua visão acerca do trabalho com a terra. Vez após outra, aliás, criavam, ou ainda melhor, recriavam hábitos à medida que iam adaptando-se à nova vida, e para isso nem sempre levavam em conta a aprovação ou não por parte dos grupos antigos na cidade. Entre esses hábitos estavam formas de lazer como os bailes.

Assim, gradativamente, poloneses e alemães, russos, italianos e austríacos, entre outros, passaram a organizar ou frequentar jogos de futebol, de cartas, corridas de cavalos, encontros dominicais e, sobretudo, bailes noturnos em que se dançavam shotz, polcas, valsas e outros ritmos europeus.

Sucede que, do ponto de vista dos donos das terras e do poder político e econômico da cidade, tais festas eram impróprias. Sempre em busca

11 ELIAS, Norbert. O processo civilizador. v. I. Rio de Janeiro: Jorge Zahar Editor, 1993.

12 BAECHLER, Jean. Grupos e Sociabilidade. In: BOUDON, Raymond (Org.). Tratado de Sociologia. Rio de Janeiro: Jorge Zahar Editor, 1995, p. 82.

13 ELIAS, Norbert; SCOTSON, John L. Os estabelecidos e os outsiders: sociologia das relações de poder a partir de uma pequena comunidade. Rio de Janeiro: Jorge Zahar Editor, 2000. 
de imitar os modismos europeus, entendiam que as festas promovidas pelos imigrantes nada mais eram do que bailes populares em que estrangeiros se misturavam a libertos, mestiços, operários, domésticas, prostitutas e a todo tipo de indivíduos por eles vistos como dispostos à bagunça e à devassidão.

De fato, como se pode desvendar a partir da leitura das fontes, os bailes promovidos pelos imigrantes eram comumente frequentados pelos luso-brasileiros, desde que conhecidos e convidados pelos donos da festa. Embora nos processos crimes não apareçam denominações como ex-escravo ou liberto, nem mesmo referência oficial à cor da pele de réus, vítima e testemunhas, faz-se claro que em tais momentos de diversão estavam presentes "os negros", como são chamados por algumas testemunhas.

Portanto, deve-se considerar que para a elite local existia uma distinção entre seus bailes e reuniões, comumente realizados em clubes sociais, nos quais as bandas contratadas embalavam as famílias com maior poder econômico e status social, em seus trajes de gala, em suas formas próprias de dançar consideradas mais corretas e elegantes, dos "divertimentos" promovidos pelos imigrantes de vida mais simples, sem grandes posses, em que eles se agrupavam a outros indivíduos, igualmente sem posses nem prestígio dentro da sociedade ponta-grossense ${ }^{14}$.

Faz-se evidente, desse modo, que para o grupo dominante não somente as características culturais dos bailes e festas promovidos pelos imigrantes eram reprováveis, já por serem diferentes do modelo que adotavam nos seus eventos, mas sobremaneira o elenco dos convidados. Eles mesmos, os imigrantes, talvez o fossem. Decerto haviam desejado a presença de imigrantes, mas para trabalhar abnegadamente no campo, produzir alimentos, cuidar da família. Não os desejavam na cidade, por entre eles, nas ruas. E, dentro da sua concepção de ambiente urbano, que crescia e que se queria moderno, ordeiro, menos ainda os desejavam fazendo barulho, bebendo, dançando, juntamente com outros homens e mulheres considerados inferiores, afinal, pobres.

14 Para uma melhor compreensão sobre as formas de diversão e as danças adotadas não somente na região dos Campos Gerais, como no Paraná ao longo do século XIX, ver: PEREIRA, Magnus R. M. Semeando iras rumo ao progresso. Curitiba: UFPR, 1997. No que se refere a Ponta Grossa, são leituras interessantes nesse sentido os seguintes livros: CHAMA, Guisela Frey. Ponta Grossa: o povo, a cidade e o poder. Ponta Grossa: PMPG, 1988; e LAVALLE, Ainda Mansani. Germânia-Guaíra: um século de sociedade na memória de Ponta Grossa. Ponta Grossa: Centro de Publicações, 1996. 
É possível vislumbrar, desse modo, o embate entre imigrantes e moradores antigos, haja vista que os primeiros não apenas deixaram de corresponder à visão romantizada do colono, como ajudavam a construir o estereótipo do estrangeiro mal-sucedido, logo, um morador não desejado.

\section{Os nacionais: defensores da ordem e do progresso}

Conforme aludido, as famílias antigas de Ponta Grossa eram defensoras do progresso econômico e social da cidade. Mais que isso, eram defensoras das novas formas de comportamento e valores republicanos.

Cabe salientar que esse momento histórico foi marcado pela instalação de outro sistema político no Brasil. Nascia a República. E com ela emergia um discurso a favor da urbanização acompanhada de inovações na organização da produção, levando ao desenvolvimento do setor industrial e à ascensão do trabalho livre. Em outras palavras, buscava-se o progresso, a riqueza e a civilização, elementos que deixariam para trás um país eminentemente agrário, com uma herança colonial escravocrata, enfim, tudo aquilo que o Império representava.

E, de fato, cidades como São Paulo, Rio de Janeiro, Belo Horizonte, Recife e Porto Alegre cresceram e transformaram-se, assistindo à construção das fábricas e dos bancos, enquanto vias férreas e portos eram ampliados. Pari passu com a ocupação do espaço urbano, surgiu uma nova assimetria nas relações sociais, impondo uma reordenação desses novos moradores, bem como um controle do poder público sobre a sociedade civil. Aliás, de acordo com Sandra Pesavento, entre os moradores da cidade agora encontrava-se "um contingente significativo de bêbados, jogadores, prostitutas e vagabundos, pessoas que viviam na 'contramão' da ordem instituída e que apresentavam comportamentos desviantes daqueles que a moral burguesa procurava impor" 15 .

15 PESAVENTO, Sandra Jatahy. O cotidiano da República. Porto Alegre: Ed. UFRGS, 1990 , p. 62. Ainda seguindo com a historiadora, tomemos como exemplo a noção de trabalho, que nesse contexto passou a ser descrito como "obrigação social", "fator de progresso" que "nobilitaria o homem". Não dedicar-se a ele, portanto, seria ir contra os ideais republicanos. 
Ponta Grossa, contudo fosse acanhada em número de habitantes se comparada às maiores cidades do país, abrigava uma elite política que buscava acompanhar tais preceitos de "modernização" do espaço urbano, alinhando-se ao discurso em defesa do progresso, da ordem e do desejo por disciplinar as massas populares, construindo assim um mundo social "à moda francesa". Concerne que, tal como nas grandes cidades, entre as "massas populares" estavam os imigrantes europeus ${ }^{16}$.

Consequentemente, embora os imigrantes aqui analisados fossem trabalhadores, como nos informam os processos criminais - haja vista que sempre declaram algum tipo de atividade, como lavradores ou agricultores, marceneiros, comerciantes -, não deixavam de "ofender" a "ordem" desejada pelo grupo dominante ao frequentar festas que não estavam em acordo com o estilo conservador e moralista por ele recomendado. Escapavam, desse modo, ao ideal do "europeu" dedicado ao trabalho, à família, dedicado a uma vida regrada e parcimoniosa, em que o tempo era usado racionalmente para produzir o sustento e a riqueza.

Retornando às fontes, é interessante refletir sobre como os membros do judiciário, representantes dessa classe dominante, interpretavam a participação dos imigrantes nessas festas. Tomem-se como exemplo os fatos ocorridos naquela noite de 1895 , quando o baile realizado na casa do negociante alemão Theodoro Mockel, localizada no Largo São João, nos arredores das ruas centrais de cidade, foi invadido por "alguns rapazes interessados em acabar com a festa" 17 .

16 Dialogando com Boris Fausto, pode-se aludir que a vida de centenas de estrangeiros que desembarcaram no Brasil para "fazer a América" se definiu para o bem ou para o mal, na luta pela sobrevivência e pela ascensão social "os sonhos se realizaram para alguns e as ilusões se desfizeram para outros". Desse modo, ao estudar a "invasão" da cidade de São Paulo pelos imigrantes, o autor percebeu que estes formaram diversas vilas e parques caóticos, sempre vistos com maus olhos pelos mais favorecidos. FAUSTO, Boris. Crime e cotidiano: a criminalidade em São Paulo (1880-1924). São Paulo: Ed. EDUSP, 2001, p. 20.

17 Processo Criminal, Laurindo Alves de Araújo, Joaquim Antonio Ribeiro, Rodrigo Alves de Almeida e Antonio José Machado; Processo por Lesões Corporais iniciado em 12 de outubro de 1895. Faz-se premente apontar que quanto à utilização de fontes criminais alinha-se a observação feita por Mariza Corrêa, segundo a qual "no momento em que os atos se transformam em autos, os fatos em versões, o concreto perde quase toda a sua importância e o debate se dá entre os atores jurídicos, cada um usando a parte do "real" que melhor reforce o seu ponto de vista". Ou seja, vítima, réu, testemunhas e membros do judiciário constroem um modelo de culpa e de inocência a partir dos elementos do "real" que lhes interessam, segundo uma lógica ordenada por um conjunto de normas sociais. Mas, como afirmou Rachel Soihet, "mesmo que os acontecimentos não tenham se passado exatamente desta ou daquela maneira, ocorre que 
"Tudo corria bem", pois o "baile era de sociedade", moças e rapazes divertiam-se ao som da gaita, quando por volta "das onze horas mais ou menos" foi perturbado por rapazes que "chegaram querendo dançar". Como estes estavam visivelmente interessados em acabar com a festa, os sócios do baile não admitiram sua entrada e fecharam as portas, no que eles "violentamente arremessaram-se sobre ela conseguindo abri-la apesar dos esforços que empregaram as pessoas que estavam dentro[...]". Ainda revoltados por não terem sido aceitos, os rapazes "descarregaram sobre a porta diversos tiros de revólver ou arma de fogo, sendo nessa ocasião ofendido levemente em uma perna por um projétil de arma de fogo Vicenti Motti”"18.

Afora a família do dono da festa, e a vítima, um italiano, aparecem nesse processo ainda os imigrantes Rodolpho Schier, alemão, ferreiro, solteiro, 24 anos, e Francisco Guzzoni, imigrante italiano, marceneiro, casado, 28 anos. Ambos passaram a ser testemunhas do crime.

Quanto aos rapazes, três brasileiros entre 20 e 25 anos, que exerciam a função de jornaleiros, evadiram-se do local assim que a festa teve fim. Denunciados, processados e levados ao tribunal, os três foram absolvidos "em conformidade com as discussões do Tribunal que respondeu por unanimidade de votos não serem os réus responsáveis do crime pelo qual são acusados"19.

Registre-se que os acusados não apresentaram qualquer testemunha a seu favor e nem mesmo negaram a invasão e as agressões, confirmadas pelo exame de corpo de delito. Ou seja, no estudo do processo não se verificou qualquer tentativa de defesa por parte dos réus, que tão somente contaram com a sorte e com a colaboração dos jurados para escapar da condenação por lesões corporais, como de fato ocorreu.

Cite-se como exemplo da tolerância do Judiciário para com os agressores dos imigrantes ainda outro processo, que igualmente serve como amostra das fontes aqui utilizadas, processo este em que a vítima foi o russo Pedro Stremel. Segundo os relatos do crime, ocorrido em 08 de junho de 1892, após uma discussão no decorrer de uma partida de bola, Pedro Mendes

as explicações encontradas são aquelas consideradas plausíveis para os agentes sociais envolvidos naquele momento, expressando a ideologia de que estão impregnados, e é isso o que nos interessa". CORRÊA, Mariza. A morte em família. Rio de Janeiro: Graal, 1983, p. 40. SOIHET, Rachel. Condição feminina e formas de violencia. Mulheres pobres e ordem urbana, 1890-1920. Rio de Janeiro: Forense Universitária, 1989, p. 14.

18 Os termos entre aspas foram retirados do processo.

19 Idem 
Campolim, baiano, mulato, "cortador de gado", agrediu o imigrante com "uma facãozada que abriu um profundo corte no braço esquerdo" ${ }^{20}$. Nas horas seguintes, todos, vítima, agressor e várias testemunhas acabaram o descanso na delegacia e depois, ao longo de alguns meses, foram interrogados repetidas vezes e apresentaram às autoridades policiais a sua versão dos fatos, usando a parte do "real" que reforçava o seu ponto de vista.

Analisando a conclusão do processo, percebe-se claramente que foi o discurso do agressor que logrou êxito, posto que o juiz, ao desonerar o acusado, declarou que "fica Pedro Campolim absolvido das penas previstas", pois os jurados, em sua maioria, entenderam que o réu não provocou o incidente, "mas puxou pela faca que sempre consigo trazia em vista da sua profissão, não com o instinto de ofender a pessoa alguma, visto não tinha outro meio de defesa [...] foi, portanto, mais a causalidade e a imprudência de Pedro Stremel a causa do desastre ${ }^{21}$.

Resulta claro em ambos os processos que as afirmações e contradições contidas nas falas dos acusados, das vítimas, bem como as entrelinhas das falas dos membros do Judiciário são indícios das relações de tensão e poder que atravessavam a vida e o convívio desses personagens. Percebe-se ainda nas falas dos juízes a condenação velada a esses "estrangeiros" que, embora agredidos, nunca tiveram seus agressores condenados. É pertinente pensar que, ao absolver os rapazes que acabaram com o baile ou o mulato que esfaqueou o russo "bêbado e esquentado", o grupo dominante promoveu uma repreensão aos imigrantes que promoviam e participavam desses encontros lúdicos, levando a efeito uma espécie de medida moralizadora, recriminando-os parcimoniosamente.

\section{A estigmatização: "polaco bêbado e briguento"}

Todavia, para além dessas formas de repreensão, a tensão entre a elite e os imigrantes dava-se também no nível das representações e do poder simbólico.

20 Processo criminal, Pedro Mendes Campolim, processo por Lesão Corporal iniciado em 08 de junho de 1892 .

21 Idem. 
Com base nas premissas já analisadas, é possível aludir que ao serem detentoras não somente do poder político e econômico, mas também jurídico da cidade, essas famílias que há muito viviam e conviviam entre si, que possuíam um passado comum, nesse outro momento histórico eram responsáveis pela construção de um modelo de cidade e de sociedade ${ }^{22}$. Vale dizer que tal modelo era acompanhado de certas representações mentais sobre um "espaço urbano" ideal, moderno, organizado.

Por sua vez, os imigrantes tinham um passado muito recente em Ponta Grossa, não compartilhavam do mesmo histórico familiar nem dos ideais de modernização das famílias antigas. Eram estranhos que agiam consciente ou inconscientemente em desacordo com algumas regras e valores do grupo dominante. Fazia-se premente então mostrar-lhes o seu papel de "inferiores" dentro dessa figuração social.

Assim, abandonou-se a versão romantizada do "colono ordeiro" perante o conflito com o imigrante real, que não abdicava de seus momentos de não trabalho e que por isso passou a ser descrito como "bêbado, esquentado e violento" ${ }^{23}$.

Efetivamente, na quase totalidade dos processos analisados faz-se o uso corriqueiro de termos que remetem a determinados traços étnicos, porém carregados com uma conotação pejorativa ou ainda de estereótipos que visam desmoralizar os grupos de origem. Nesse sentido, não raro os personagens lançavam mão de expressões como "o polaco" para referir-se a qualquer imigrante, fosse ele russo ou alemão ou austríaco, acrescendo-se ainda defeitos que seriam característicos a todos os membros de um grupo e do outro, pois todo "polaco" seria "bêbado". Convém acrescentar que embora não se utilizassem dos mesmos termos pejorativos, os magistrados eram veladamente favoráveis, posto que na conclusão dos processos

22 Resguardadas as profundas diferenças históricas entre os grupos investigados por Elias na pequena cidade do interior da Inglaterra e estes que pertenciam à sociedade ponta-grossense, torna-se plausível uma aproximação com a perspectiva de análise do autor. Assim, tomando-a como exemplo, percebe-se que, entre os moradores que há mais tempo habitavam Ponta Grossa, alguns não somente ocupavam as posições de prestígio como também serviam como modelos de conduta dentro dessa configuração social. Entenda-se como "estabelecidos", portanto, os descendentes dos primeiros povoadores ou proprietários das grandes fazendas que existiam na região, indivíduos que haviam herdado não somente um patrimônio material, mas, sobretudo, simbólico no campo político e econômico. ELIAS, Norbert; SCOTSON, John L. Os estabelecidos e os outsiders: sociologia das relações de poder a partir de uma pequena comunidade. Rio de Janeiro: Jorge Zahar Ed., 2000.

23 Processo criminal, Pedro Mendes Campolim, op. cit. 
consideravam os imigrantes como de fato homens propensos à violência e ao alcoolismo.

Seria lícito pensar, em consonância com os estudos de Pierre Bourdieu sobre identidade e representação, que se tratava de uma "luta de classificação", luta de "poder impor uma visão do mundo social através de princípios de divisão que, quando se impõem ao conjunto do grupo, realizam o sentido e o consenso sobre o sentido e, em particular, sobre a identidade e a unidade do grupo"24. Assim, de um modo geral, pode-se dizer que as famílias antigas atribuíam a si poder de impor a sua visão de mundo aos demais moradores e, consequentemente, o poder de anunciar a divisão do mundo social que lhes interessava, mantendo-se sempre como o grupo de maior carisma e valor humano.

Vale lembrar que enquanto moradores antigos de Ponta Grossa, herdeiros de uma sociedade conservadora e hierarquizada, a elite sempre defendeu uma espécie de continuação da estratificação social a que estava acostumada, usando as estratégias que estavam ao seu alcance para manter o seu status e as vantagens que lhes eram correlatas ${ }^{25}$.

Concerne que entre tais vantagens estava a "autoridade", como nos informa o sociólogo francês, de dizer "à vista de todos e em nome de todos, publicamente e oficialmente", quais eram as normas e comportamentos adequados ao espaço urbano. Indo mais além, o poder de "anunciar" qual era o papel e a posição de cada indivíduo e cada grupo nesse espaço ou de "anunciar" quais dentre eles eram bem-vindos e quais eram indesejados. Ao fim e ao cabo, estava em suas mãos o poder de estigmatizar os indivíduos e de torná-los "trabalhadores abnegados" ou "bêbados" aos olhos dos demais.

Todavia, se tal discurso era "conhecido e reconhecido" pelos demais moradores da cidade, entre os imigrantes não o era. Nascia a luta contra o estigma.

\section{Baile "de boa sociedade": a defesa dos imigrantes}

Na leitura dos processos criminais, percebe-se claramente a defesa por parte desses outsiders de seus valores e costumes, da imagem de si, da

24 BOURDIEU, Pierre. O poder simbólico. Rio de Janeiro: Ed. Bertrand, 1989, p. 113.

25 ELIAS, Norbert; SCOTSON, John L. Os estabelecidos e os outsiders..., op.cit., 2000. 
sua identidade. Doravante, ao invés de arrefecerem a identidade negativa a eles imposta, esses homens e mulheres buscaram se apropriar das vantagens de avaliar-se e serem avaliados segundo princípios mais favoráveis. Para mais uma vez dialogar com Bourdieu: "Sabe-se que os indivíduos e os grupos investem nas lutas de classificação todo o seu ser social, tudo o que define a ideia que eles têm deles próprios, todo o impensado pelo qual eles se constituem como 'nós' por oposição a 'eles', aos 'outros' [...] É isto que explica a força mobilizadora excepcional de tudo o que toca à identidade"26.

Conquanto individualmente não tivessem meios para lutar contra $o$ estigma, não tendo outra escolha senão aceitar de forma resignada, submissa ou provocante a imagem construída pelo grupo dominante sobre si, fazia-se necessária a união, uma luta coletiva pela supressão "não das características estigmatizadas, mas da tábua de valores que as constituía como estigma"27.

Italianos, alemães e russos, poloneses e austríacos, passaram a ser iguais na diferença.

Decerto vieram ao Brasil para trabalhar e, quiçá, enriquecer, acumular melhores condições financeiras do que aquelas que obteriam permanecendo na Europa, mas nem por isso deixariam de desfrutar os momentos de não trabalho, as horas de descanso, à sua maneira. Não deixariam de frequentar os bailes, posto que esses não eram momentos de lascívia ou bagunça, mas sim encontros de "boa sociedade".

Portando gaitas, tocando violão, cantando ou dançando, jogando e namorando, os imigrantes estavam presentes em todas as "festas" narradas nos processos. Nas suas falas aos delegados e juízes, os bailes eram descritos sempre como sendo "de sociedade", "de boa sociedade", "de família"28.

26 BOURDIEU, Pierre. O poder simbólico. Op. cit., p. 125.

27 Idem, p. 124, nota 20.

28 Os termos entre aspas foram retirados dos processos. Cabe ressaltar que para a elaboração desse trabalho foram analisados cinco processos criminais. Assim, afora os processos já citados, foram usadas ainda as seguintes fontes: Processo Criminal por Desacato e Desobediência, João Rubino do Prado, iniciado em 06 de agosto de 1892; Processo Criminal por Lesão Corporal, Martinho Bahls, iniciado em 11 de março de 1895; Processo por Homicídio, Honório Bernardo Munhóz e Francisco Padilha dos Santos, iniciado em 22 de outubro de 1899. Como já foi apontado em outros trabalhos historiográficos, tais fontes são ricas em informações, trazendo os dados pessoais dos acusados, ofendidos e testemunhas, data e hora da ocorrência, comportamentos dos envolvidos, relações de amizade e de conflito, falas de juízes, promotores e advogados, as práticas da justiça, leituras sobre Direito e sobre sociedade, enfim, uma vasta gama de representações e visões de mundo que instigam o historiador. Deve-se destacar, por fim, que todos os processos utilizados foram reproduzidos a partir de fontes pesquisadas junto ao acervo do Departamento de História da UEPG, acervo este que guarda os processos criminais mais antigos da Comarca de Ponta Grossa em excelente estado de conservação e sob cuidados especiais de manuseio e armazenagem. 
Terminavam em desavenças, mas isso se devia aos brasileiros que não sabiam respeitá-los, que forçavam a entrada, não respeitavam as mulheres e que, advertidos sobre a conduta inadequada, os agrediam, seja com golpes de porrete, com facadas e "facãozadas", seja a tiros ${ }^{29}$.

Por este ângulo, pode-se afirmar que, deixando de negar-se em proveito do grupo dominante, os imigrantes foram forçosamente levados a reconstruir suas identidades culturais do outro lado do Atlântico frente a um contexto de conflitos e tensões que, por certo, não estavam entre as suas preocupações quando por aqui aportaram. Ou seja, foi o encontro, ou melhor, o "desencontro" com os nacionais que os fez visualizar-se como diferentes, mas nem por isso como "inferiores".

Como lembra Denys Cuche, autor que, ao analisar a questão da identidade cultural, concluiu que esta "é uma construção que se elabora em uma relação que opõe um grupo aos outros grupos com os quais está em contato", deve-se sempre ter em vista que a "construção da identidade se faz no interior de contextos sociais que determinam a posição dos agentes e por isso mesmo orientam suas representações e suas escolhas" ${ }^{\prime 30}$.

Dessa maneira, o autor defende uma concepção relacional e situacional da identidade, cujas bases aponta como sendo dadas por Frederik Barth; assim, "uma cultura particular não produz por si só uma identidade diferenciada: esta identidade resulta unicamente das interações entre os grupos e os procedimentos de diferenciação que eles utilizam em suas relações"31.

Dentro dessa perspectiva, não há identidade em si, nem mesmo unicamente para si, posto que a identidade existe sempre em relação a uma outra. Logo, tornou possível pensar que após virem à tona as diferenças entre o grupo estabelecido na cidade e os imigrantes é que os traços identitários desses últimos ganharam contornos mais definidos. Ou, em palavras mais diretas, após a afirmação da alteridade deu-se a afirmação da identidade.

29 Informações retiradas das fontes.

30 CUCHE, Denys. A noção de cultura nas Ciências Sociais. Bauru: EDUSC, 1999, p. 182. Cuche aborda as limitações que as noções de identidade baseadas em teorias objetivistas e subjetivistas apresentam, pois, se as primeiras consideram os indivíduos como seres estáticos que recebem sua identidade pronta e acabada no interior de um grupo etnocultural, as segundas, buscando mostrar o caráter mutável da identidade, pecam ao enfatizar excessivamente o seu aspecto efêmero. Em sua opinião, "adotar uma abordagem puramente objetiva ou puramente subjetiva para abordar a questão da identidade seria se colocar em um impasse. Seria raciocinar fazendo a abstração do contexto relacional" (p. 181). Somente este contexto poderia explicar, num dado momento, por que tal identidade é afirmada ou reprimida.

31 Idem, p. 182. 


\section{Conclusão}

Alinhando-se às discussões de Norbert Elias acerca das relações de poder entre grupos sociais, entende-se que os processos migratórios, "às vezes, são concebidos simplesmente como aspectos geográficos: tudo o que parece acontecer é as pessoas se deslocarem fisicamente de um lugar para o outro. Na realidade, elas sempre se deslocam de um grupo social para outro. Sempre têm que estabelecer novos relacionamentos com os grupos já existentes" ${ }^{\prime 2}$. Todavia, esse processo de ressocialização nem sempre transcorria de maneira tranquila, sem traumas, sem desencontros. Perante os evidentes indícios fornecidos pelas fontes, para muitos imigrantes esse processo foi bastante tumultuado.

Nesse sentido, embora esses indivíduos tenham modificado suas "ideias" e "necessidades" a partir da sua inserção na sociedade ponta-grossense - posto que também nela eram atores participantes do eterno tecer e destecer das relações sociais e não seres imóveis e imutáveis -, não puderam escapar do embate com os moradores estabelecidos em Ponta Grossa. Para sua desvantagem, estava nas mãos deles o poder de enunciar, aberta ou veladamente, a sua melhor posição na sociedade local.

Foi possível desvelar que muitos alcançaram o objetivo de adaptar-se ao espaço urbano e em pouco tempo acabaram, com seu trabalho, vencendo as resistências e conquistando o respeito e, muitas vezes, a amizade dos antigos moradores ${ }^{33}$.

Entretanto, muitos outros, certamente a grande maioria, não atingiram o objetivo de melhorar de vida, que sem dúvida era uma das principais motivações para atravessar o Atlântico e aventurar-se nesse outro mundo social. Para eles, as ilusões se desfizeram.

Com efeito, foram as falas desse último grupo, os "imigrantes pobres", que ficaram narradas nos processos criminais, documentos da Comarca de Ponta Grossa que os apresentava nas entrelinhas como contra-

174.

32 ELIAS, Norbert; SCOTSON, John L. Os estabelecidos e os outsiders..., op.cit., 2000, p.

33 Cite-se o caso do imigrante alemão Henrique Thielen, que, produzindo cervejas artesanais que vendia de porta em porta, chegou a fundar uma fábrica de bebidas, a Cervejaria Adriática, enriquecendo e ganhando respeito em meio à elite local. Thielen foi várias vezes eleito vereador na cidade. 
ventores, mesmo quando vítimas, empurrando-os para um papel à margem na sociedade local.

Para delegados, juízes e promotores, reconhecidos representantes da elite ponta-grossense e defensores dos ideais republicanos, mais que outsiders os imigrantes eram indivíduos desordeiros, amorais.

No entanto, importa-nos verificar que, longe de deixar-se submeter totalmente ao grupo dominante, esses imigrantes desmistificaram a sociedade ideal, reinventando o espaço urbano, num jogo de resistência e oposição. Vez após outra escapavam a essa relação de coerção e se tornavam indiferentes à reprovação velada ou declarada aos seus bailes e festas e jogos. Continuavam a promovê-los. Continuavam a tecer relações de amizade com os nacionais, com pessoas vindas de outras cidades e mesmo de outros estados, ou imigrantes de outras nacionalidades, enfim, indivíduos que como eles não eram detentores de posses, que como eles enfrentavam as mesmas dificuldades no cotidiano para encontrar lugar no mercado de trabalho, para sustentar-se ou sustentar a família, derrubar as barreiras que encontravam para serem aceitos na sociedade local e deixar o estigma de recém-chegados para trás.

Todavia, uma vez confrontados pela elite local, longe de deixar-se submeter, esses homens e mulheres não arrefeceram a condenação de seus hábitos e costumes, a construção do estereótipo de estrangeiro bêbado e bagunceiro, a imagem negativa que lhes era imputada. Uniram-se. E defenderam-se.

Percebiam-se como pessoas de "boa sociedade", e como tal, gostavam de beber, de jogar cartas, de dançar... gostavam de festar... e nisso pouco ou nada importava a reprovação ou não das família antigas.

Recebido em julho de 2010. Aprovado em novembro de 2010. 